\title{
Fast Scan Cyclic Voltammetry as a Novel Method for Detection of Real-Time Gonadotropin-Releasing Hormone Release in Mouse Brain Slices
}

\author{
Katarzyna M. Glanowska, ${ }^{1}$ B. Jill Venton, ${ }^{2}$ and Suzanne M. Moenter ${ }^{3}$ \\ ${ }^{1}$ Neuroscience Graduate Program and ${ }^{2}$ Department of Chemistry, University of Virginia, Charlottesville, Virginia 22908, and ${ }^{3}$ Departments of Molecular \\ and Integrative Physiology, Internal Medicine, and Obstetrics and Gynecology, University of Michigan, Ann Arbor, Michigan 48109-5622
}

Pulsatile gonadotropin-releasing hormone $(\mathrm{GnRH})$ release is critical for the central regulation of fertility. There is no method allowing real-time GnRH detection in brain slices. We developed fast-scan cyclic voltammetry (FSCV) using carbon-fiber microelectrodes (CFME) to detect $\mathrm{GnRH}$ release and validated it using a biologically relevant system. FSCV parameters (holding potential, switching potential, and scan rate) were determined for stable GnRH detection in vitro, then optimized for GnRH detection in mouse brain slices. Placement of CFMEs in the median eminence (ME) near GnRH terminals allowed detection of both KCl-evoked and spontaneous GnRH release. GnRH release was also detected from GnRH fibers passing near GnRH soma and near fiber-fiber appositions in the preoptic area. No GnRH signal was detected from CFMEs in the ME of $h p g$ mice, which lack GnRH, or in regions not containing GnRH neurons in wild-type mice; application of exogenous GnRH produced a signal similar to that observed for spontaneous/evoked endogenous GnRH release. Using an established mouse model that produces diurnal variations in GnRH neuron activity, we demonstrated corresponding changes in spontaneous GnRH release in the median eminence. These results validate FSCV to detect GnRH in brain slices and provide new information on the sites and amounts of GnRH release, providing insight into its neuromodulatory functions.

\section{Introduction}

Pulsatile gonadotropin-releasing hormone $(\mathrm{GnRH})$ release is essential for fertility (Belchetz et al., 1978). GnRH is released from terminals in the median eminence (ME) near pituitary portal vessels. Modulation of GnRH pulse frequency is required for the differential release of luteinizing hormone (LH) and folliclestimulating hormone from the pituitary that is crucial for driving female reproductive cycles (Wildt et al., 1981). Abnormal GnRHpulse patterns can cause infertility (McCartney et al., 2002). In addition to release at the ME, GnRH may act as a neuromodulator in local circuits (DePaolo et al., 1987; Xu et al., 2004, 2008; Chen and Moenter, 2009; Han et al., 2010), but release has not been demonstrated from other brain regions in situ.

Recent work has examined the pattern of action-potential firing from $\mathrm{GnRH}$ neurons in brain slices and primary cultures (Kuehl-Kovarik et al., 2002; Nunemaker et al., 2003; Abe and Terasawa, 2005; Christian et al., 2005; Pielecka and Moenter, 2006; Pielecka et al., 2006; Lee et al., 2010). There is no empirical

Received March 15, 2012; revised Aug. 17, 2012; accepted Aug. 22, 2012.

Author contributions: K.M.G., B.J.V., and S.M.M. designed research; K.M.G. performed research; K.M.G. analyzed data; K.M.G., B.J.V., and S.M.M. wrote the paper.

This work was supported by National Institute of Health/Eunice Kennedy Shriver National Institute of Child Health and Human Development Grant R01 HD34860. We thank Debra Fisher and Laura Burger for expert technical assistance.

Correspondence should be addressed to Suzanne M. Moenter, Department of Molecular and Integrative Physiology, University of Michigan, 7725 Med Sci II, 1137 E. Catherine St, Ann Arbor, MI 48109-5622. E-mail: smoenter@umich.edu.

DOI:10.1523/JNEUROSCI.1303-12.2012

Copyright $\odot 2012$ the authors $\quad 0270-6474 / 12 / 3214664-06 \$ 15.00 / 0$ link, however, between the firing pattern of GnRH neurons and the pattern of release produced. This is attributable to a lack of a method that allows for GnRH-release detection in preparations used for electrophysiology.

GnRH contains electrochemically active amino acids, in particular tryptophan and tyrosine. Electochemically active species can be detected and identified using fast scan cyclic voltammetry (FSCV) based on their oxidation and reduction properties. This method has been used to detect small molecule neurotransmitters, such as monoamines (Cahill et al., 1996). Our objectives were to adapt FSCV to enable GnRH detection in brain slices, to determine where release occurs, and to test the ability of FSCV to detect biologically relevant changes in GnRH release.

\section{Materials and Methods}

Carbon-fiber microelectrodes fabrication. Carbon-fiber microelectrodes (CFMEs) were fabricated as described previously (Mundroff and Wightman, 2002). Carbon fiber (T-650; a gift from Cytec Engineering Materials) was aspirated into a capillary glass tube (1.65/1.1 mm OD/ID; World Precision Instruments), which was pulled (PE-21; Narishige; or P-97; Sutter Instruments). The fiber was cut to $40-60 \mu \mathrm{m}$ and sealed to the glass using Epoxy Resin 858 (Miller-Stephenson) and 14\%(w/w) $\mathrm{m}$-phenylenediamine (Fluka). Electrodes were incubated overnight at room temperature, baked for $2 \mathrm{~h}\left(100^{\circ} \mathrm{C}\right)$ and then overnight $\left(150^{\circ} \mathrm{C}\right)$. Before experiments, electrodes were washed $\leq 10 \mathrm{~min}$ in isopropanol and then filled with $1 \mathrm{~m} \mathrm{KCl}$.

FSCV in vitro. Chemicals were from Sigma unless otherwise noted. Data were collected using a custom-modified Dagan ChemClamp potentiostat and Tar Heel software (a gift from Mark Wightman, University of North Carolina at Chapel Hill, Chapel Hill, NC) or an extended range 
A

A

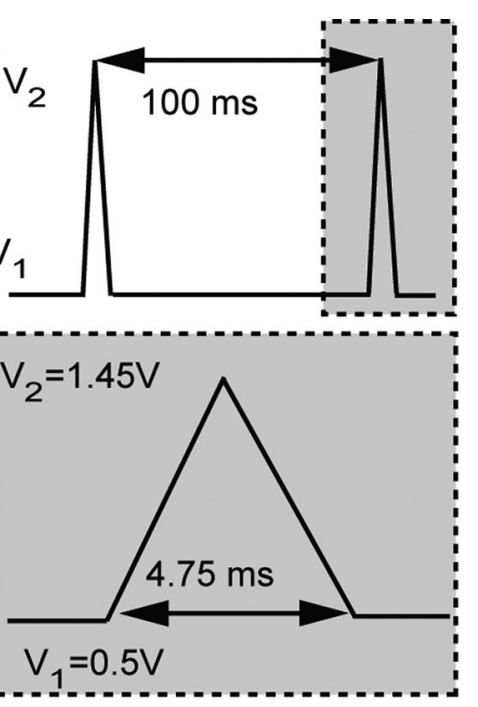

B

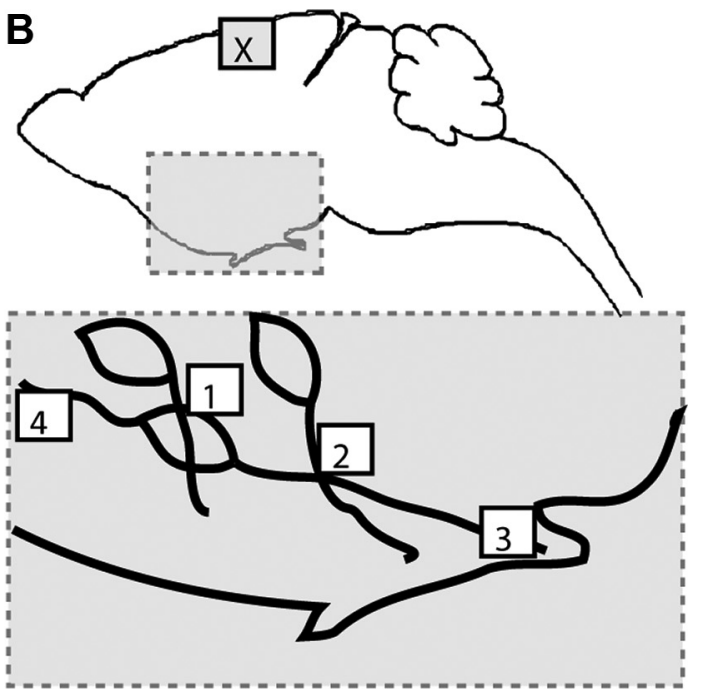

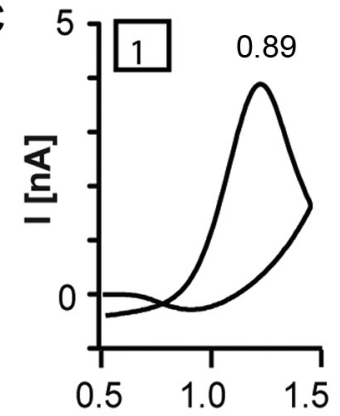

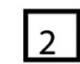

0.97
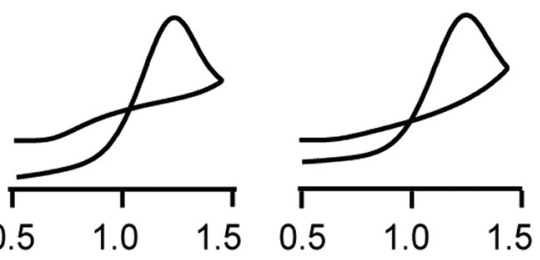

4

0.10

\section{potential [V]}

Figure 1. A, FSCV protocol used to detect GnRH. $V_{1}$ is holding potential, $V_{2}$ is switching potential. Gray area is expanded below. B, Illustration of recording sites. Top, Sagittal section; gray area is expanded below. X indicates location of CFMEs for exogenous GnRH application. Bottom, Sites of GnRH release: 1, GnRH soma-fiber contact (POA); 2, GnRH fiber-fiber contact (POA); 3, GnRH terminals in the ME; 4, single GnRH fiber (POA). C, Example CVs taken at peak current of GnRH signal detected in locations indicated in $B, R^{2}$ is in top right corner.

$( \pm 2$ V) EPC10 patch-clamp with PatchMaster (HEKA Elektronic) with Demon Voltammetry (Wake Forest University, Winston-Salem, NC). In vitro experiments were done in $\mathrm{pH} 7.4$ Tris buffer containing the following (in $\mathrm{mm}$ ): 15 tris(hydroxymethyl)aminomethane, $140 \mathrm{NaCl}$, $3.25 \mathrm{KCl}, 1.2 \mathrm{CaCl}_{2}, 1.25 \mathrm{NaH}_{2} \mathrm{PO}_{4}, 1.2 \mathrm{MgCl}_{2}$, and $2.0 \mathrm{Na}_{2} \mathrm{SO}$, as described previously (Strand and Venton, 2008). CFMEs were calibrated in vitro using a flow-injection apparatus. Injections ( $3 \mathrm{~s}$ ) of compounds of interest ( $1 \mu \mathrm{M}$ tryptophan or $5 \mu \mathrm{M} \mathrm{GnRH}$ in Tris buffer) were used to mimic fast concentration changes expected in biological systems. For both tryptophan and $\mathrm{GnRH}$, the waveform parameters (holding and switching potentials, and scan rate) were optimized toward detection of the single, specific oxidation peak.

Animals. Transgenic mice expressing green fluorescent protein (GFP) under the control of the GnRH promoter (GnRH-GFP) (Suter et al., 2000 ) were used for spontaneous and evoked release studies. To control for specificity, hypogonadal ( $h p g)$ GnRH-GFP-hpg mice ( $h p g-G n R H-$ GFP; a gift from Drs. Ursula Kaiser and John Gill, Brigham and Women's Hospital, Harvard Medical School, and Harvard Reproductive Endocrine Sciences Center, Boston, MA) (Gill et al., 2008); these mice lack GnRH peptide (Mason et al., 1986). Tac2-GFP transgenic mice (015495UCD/ STOCK Tg (Tac2-EGFP)381Gsat; Mouse Mutant Regional Resource Center) were used as a positive control for detecting evoked GnRH release without GFP identification of terminals.

Mice were housed under a 14:10 h light:dark photoperiod with Harlan 2916 chow and water available ad libitum. Adult females (42-60 d) were used. Ovariectomy (OVX) was performed under isoflurane (Burns Veterinary Supply) anesthesia. Bupivicaine $(0.25 \%, 7 \mu \mathrm{l}$ per surgical site; Abbott Labs) was applied to surgery sites to reduce postoperative pain and distress. During OVX, mice received subcutaneous SILASTIC (DowCorning) implants containing $0.625 \mu \mathrm{g}$ of $17 \beta$-estradiol (E) in sesame oil with or without progesterone $(\mathrm{P})$ implants $(2.5 \mathrm{mg}$; Innovative Research of America). OVX +E mice, which generated daily LH surges (Christian et al., 2005), were used 2-4 d postsurgery; OVX $+E+P$ mice were used 5-10 d postsurgery. All procedures were approved by the University of Virginia Animal Care and Use Committee and the University of Michigan University Committee on the Use and Care of Animals.

FSCV in brain slices. Brain slices were prepared as described previously (Nunemaker et al., 2002; Chu and Moenter, 2005). All buffers were bubbled with $95 \% \mathrm{O}_{2} / 5 \% \mathrm{CO}_{2} \geq 15$ min before usage. Sagittal (OVX $+\mathrm{E}+\mathrm{P}$ and OVX $+\mathrm{E}$, morning vs afternoon) or coronal ( $h p g$ and Tac2 mice) 300 $\mu \mathrm{m}$ brain slices were cut using a Vibratome 3000 (Ted Pella) in ice-cold sucrose saline containing the following (in $\mathrm{mM}$ ): 250 sucrose, $3.5 \mathrm{KCl}, 26$ $\mathrm{NaHCO}_{3}, 10$ glucose, $1.25 \mathrm{NaH}_{2} \mathrm{PO}_{4}, 1.2 \mathrm{MgSO}_{4}$, and $3.8 \mathrm{MgCl}_{2}$. Slices were incubated $30 \mathrm{~min}$ at $30-32^{\circ} \mathrm{C}$ in a $1: 1$ mixture of sucrose saline and artificial CSF (ACSF) containing the following (in $\mathrm{mM}$ ): $125 \mathrm{NaCl}, 3.5$ $\mathrm{KCl}, 26 \mathrm{NaHCO}_{3}, 1.25 \mathrm{NaH}_{2} \mathrm{PO}_{4}, 2.5 \mathrm{CaCl}_{2}, 1.2 \mathrm{MgSO}_{4}$, and 10 D-glucose, pH 7.4, then transferred to $100 \%$ ACSF and incubated 30-300 min at room temperature before study.

For GnRH detection, potential was continuously scanned from 0.5 to $1.45 \mathrm{~V}$ at $400 \mathrm{~V} / \mathrm{s}$ every $100 \mathrm{~ms}$ (Fig. $1 \mathrm{~A}$ ). CFMEs were stabilized for 15 min before collecting data. Signals arising from spontaneous release were recorded for 20 min either in the ME or preoptic area (POA), and then secretion was evoked by a $20 \mathrm{~mm} \mathrm{KCl} \mathrm{ACSF}$. For biological validation of hypothesized changes in GnRH release with time of day in OVX+E mice, $\mathrm{GnRH}$ release was monitored continuously for $1 \mathrm{~h}$ with CFMEs placed 

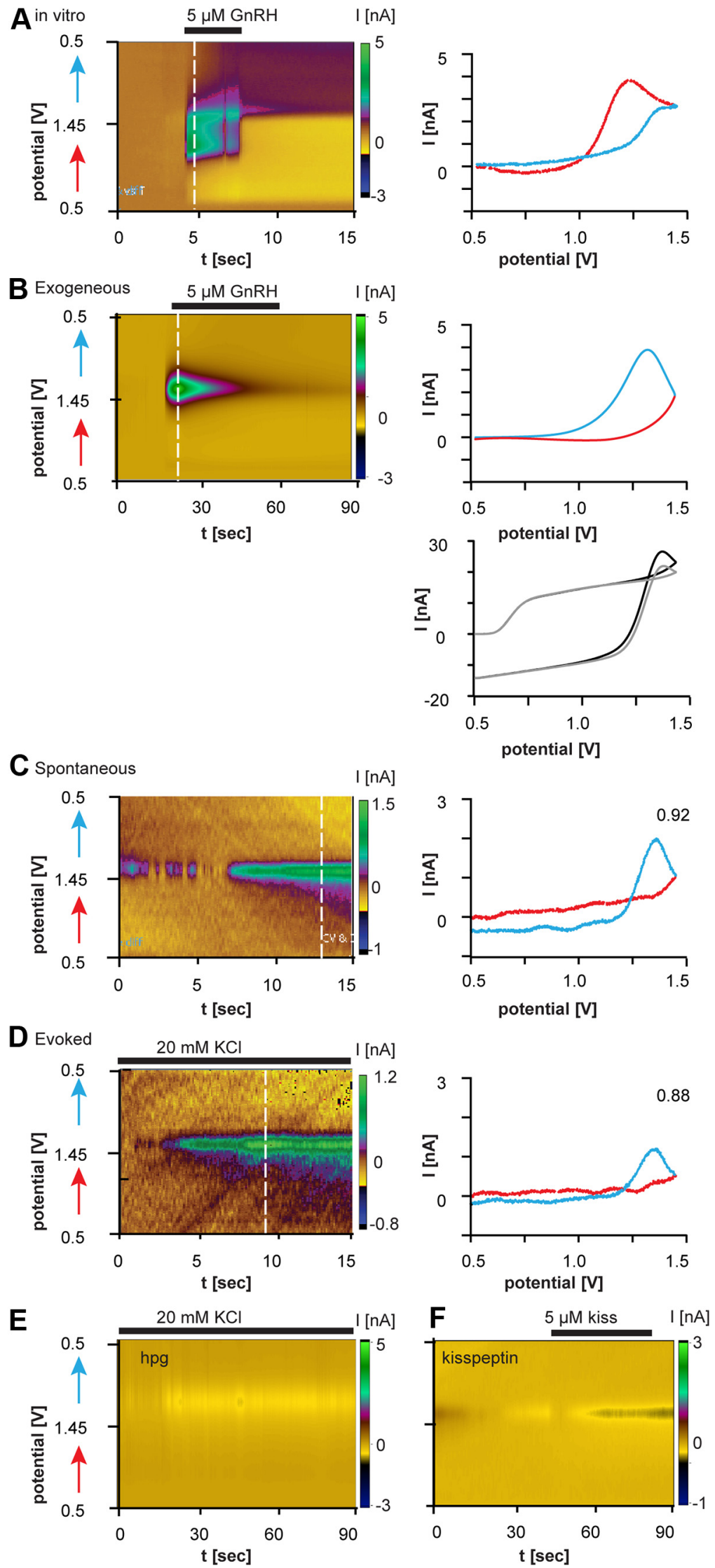

Figure 2. FSCV recordings of evoked and spontaneous $G n R H$ release monitored by CFMEs in brain slices. $A, C, D$, Recordings from CFMEs in the median eminence. $\boldsymbol{B}, \boldsymbol{F}$, Recordings from CFMEs in cortex. $\boldsymbol{A}-\boldsymbol{D}$, Left, Electrochemical current in a color heat plot as a function of voltage and time (left). Red arrows show the forward voltage scan and blue arrows show the reverse scan. Dotted white lines indicate time for which cyclic voltammogram is plotted on the right. $\boldsymbol{A}$, In vitro $\mathrm{GnRH}$ signal. $\boldsymbol{B}$, Exogenous $\mathrm{GnRH}$ applied in either near GnRH neuron terminals in the ME or in the POA near fiber-soma appositions.

CFMEs were placed in the cortex or hippocampus, away from GnRH soma/processes, to perform controls. To document the GnRHgenerated FSCV signal in the brain slice environment, $5 \mu \mathrm{M}$ GnRH was applied near CFMEs. To control for specificity, kisspeptin $(5 \mu \mathrm{M})$, which may be released in the ME, was applied near CFMEs in the cortex/hippocampus. In addition, CFMEs were placed in the ME of $h p g$-GnRH-GFP mice and Tac2-GFP mice, and $\mathrm{KCl}$-evoked signal examined. Following all recordings, CFMEs were calibrated in $5 \mu \mathrm{M}$ $\mathrm{GnRH}$ in vitro.

Data analysis. Data were analyzed using Tar Heel or Demon software (Wake Forest University Health Sciences) as described previously (Mundroff and Wightman, 2002). Cyclic voltammograms (CVs) were background-subtracted by averaging 10 background scans. To verify the identity of a spontaneous release peak as $\mathrm{GnRH}$, five control CVs collected after GnRH was injected into a slice were averaged. Each putative GnRH CV was correlated with this average and was considered to be GnRH if $R^{2} \geq 0.8$. This threshold was set to allow for some electrode variability. Ninety-six percent of CVs passed this test; those with $R^{2}<0.8$ were always flanked by events with robust correlations. For the daily surge experiment $(\mathrm{OVX}+\mathrm{E}$ animals), data were binned at 1 min intervals to facilitate evaluation of the pattern of release. Maximum change in GnRH concentration for each $1 \mathrm{~min}$ bin was plotted versus time (Fig. 2A). Event duration was the number of consecutive bins in which a change in GnRH was detected; events separated by a single $1 \mathrm{~min}$ bin without detection of $\mathrm{GnRH}$ were considered to be single events. Changes in GnRH concentration were estimated based on calibration in $5 \mu \mathrm{M}$ GnRH. Data are expressed as mean \pm SEM and analyzed using ANOVA with Bonferroni post hoc test (GraphPad Prism); $p<0.05$ was considered significant.

\section{Results \\ Detecting tryptophan and GnRH in vitro}

FSCV parameters were optimized for stable in vitro detection of tryptophan (1 $\mu \mathrm{M})$. Holding potential (potential at the start $0.4-0.6 \mathrm{~V}$ ), switching potential (potential at the peak $1.1-1.3 \mathrm{~V}$ ), scan rate $(50-500 \mathrm{~V} / \mathrm{s})$, and waveforms were varied within the ranges indicated. Tryptophan is known to foul the electrode under some conditions (Paras and Kennedy, 1995), so

cortex generates a similar cyclic voltammogram to endogenous GnRH ( $\boldsymbol{C}, \boldsymbol{D})$. B , Bottom right, Raw background voltammograms in the presence (black trace) and absence (gray) of GnRH. C, Spontaneous GnRH release in GnRH-GFP mouse. $D$, $\mathrm{KCl}$-evoked GnRH release in GnRH-GFP mouse. For $\mathbf{C}$ and $\boldsymbol{D}, R^{2}$ is in top right corner. $\boldsymbol{E}$, No $\mathrm{GnRH}$ release evoked by $\mathrm{KCl}$ in the ME of $h p g$ mice, which lack GnRH. $\boldsymbol{F}$, Exogenous kisspeptin applied in the cortex does not generate a signal. 
Table 1. Summary of control experiments

\begin{tabular}{lllrl}
\hline Location & Genotype & Treatment & $n$ & $\mathrm{nA}$ \\
\hline Cortex/hippocampus & GnRH-GFP & $20 \mathrm{mM} \mathrm{KCl}$ & 5 & 0 \\
Cortex/hippocampus & GnRH-GFP & $5 \mu \mathrm{M}$ GnRH & 10 & $1.6 \pm 0.4$ \\
Cortex/hippocampus & GnRH-GFP & $5 \mu \mathrm{m}$ kisspeptin & 3 & 0 \\
Median eminence & hpg & $20 \mathrm{mM} \mathrm{KCl}$ & 9 & 0 \\
Median eminence & Tac2-GFP & $20 \mathrm{mM} \mathrm{KCl}$ & 7 & $3.3 \pm 0.7$ \\
\hline
\end{tabular}

FSCV parameters were chosen to minimize loss of sensitivity and produce consistent cyclic voltammograms (data not shown). The oxidation peak for $1 \mu \mathrm{M}$ tryptophan was $0.9 \mathrm{~V}$, whereas the oxidation peak was shifted to higher voltages $(\sim 1.25 \mathrm{~V})$ for $5 \mu \mathrm{M}$ GnRH (Fig. 2A). This shift in peak may be attributable to slower kinetics of tryptophan oxidation when it is incorporated into the peptide. The peak signal obtained for $5 \mu \mathrm{M} \mathrm{GnRH}$ with the optimized waveform of $0.5 \mathrm{~V}$ to $1.45 \mathrm{~V}$ at $400 \mathrm{~V} / \mathrm{s}$ (Fig. $1 A$, voltage protocol) was $2.5 \pm 0.1 \mathrm{nA}(n=5)$.

\section{FSCV in mouse brain slices}

We next recorded from GFP-identified GnRH neurons in brain slices (Suter et al., 2000). Female OVX +E+P mice were used as this treatment produces low endogenous $\mathrm{GnRH}$ neuron activity (Pielecka et al., 2006). Because FSCV detects changes in concentration rather than absolute concentration, a low baseline was desired for initial tests. CFMEs were positioned near GFPidentified terminals in the ME. After stabilization, data were collected for $20 \mathrm{~min}$ to reveal any spontaneous release, followed by treatment with $20 \mathrm{~mm} \mathrm{KCl}$ to evoke release. Both spontaneous and evoked GnRH release were detected (Fig. 2C,D; Table 1). The peak oxidation potential was shifted to slightly higher voltages in the brain slice $(1.32 \pm 0.02 \mathrm{~V})$ than was observed in vitro $(1.20 \pm$ $0.05 \mathrm{~V})$. Although the current flow indicates oxidation, the peak occurs during the return of the voltage from switching potential to holding potential. This is likely attributable to slower electron transfer kinetics in electrodes placed in tissue; this was expected as the surrounding milieu for the peptide is different. To test whether changes in milieu between pure buffer and the brain slice would cause a similar shift in cyclic voltammogram, CFMEs were positioned in the cortex or hippocampus and $5 \mu \mathrm{M}$ GnRH locally applied. The signal obtained (Fig. $2 B$; Table 1$)$ was similar $\left(R^{2}>\right.$ 0.8 ) to that for spontaneous and evoked release of $\mathrm{GnRH}$ detected by CFMEs in the ME (Fig. 2C,D; Table 1). The signal observed for mammalian GnRH differs from that of teleosts (Ishizaki and Oka, 2001), likely due to different materials of the CFME and amino acid sequence.

The presence of tryptophan and tyrosine in many proteins raises an obvious question of specificity. In this regard, tryptophan and tyrosine are hydrophobic, tending to be on the inside of folded proteins (Chothia, 1976; Miller et al., 1987), and thus minimizing interference from large proteins, as these amino acids are inaccessible for oxidation. When tryptophan and tyrosine are accessible as in smaller peptides like $\mathrm{GnRH}$, surrounding amino acids will influence the oxidation profile; thus it should be unique for each substance. We tested specificity in several ways (Table 1; Fig. 2E,F). First, no GnRH signal was observed in brain regions lacking $\mathrm{GnRH}$ peptide even in the presence of high potassium to evoke release (data not shown). Second, the small tryptophancontaining peptide kisspeptin-10 $(1-5 \mu \mathrm{M})$ did not produce a signal similar to that of $\operatorname{GnRH}\left(R^{2}=0.01\right.$; Fig. $\left.2 F\right)$. Third, no GnRH signal was evoked by high potassium from the ME of $h p g$ mice, which have no detectable GnRH peptide despite a normal distribution of GnRH and other neuroendocrine neurons (Fig.
2E) (Gill et al., 2008). In contrast to the lack of GnRH signal in $\mathrm{ME}$ from $h p g$ mice, typical potassium-induced $\mathrm{GnRH}$ release was recorded from the ME of control mice, even when CFME placement was guided solely by anatomy (i.e., no GnRH-GFP signal, $R^{2} \geq 0.8$; Table 1). Finally, it should be noted that although voltammetry is used to detect small neurotransmitters such as catecholamines, these neurotransmitters oxidize at much lower voltages, near the holding potential in these experiments (Venton et al., 2002). Thus, no signal would be expected from these substances, as they are already oxidized. Together, these data suggest the signal is specific for $\mathrm{GnRH}$.

\section{Sites of endogenous $\mathrm{GnRH}$ release}

We next tested sites of GnRH release. CFMEs were positioned: (1) in the POA between GnRH fibers and somata, (2) in the POA where GnRH fibers crossed one another, (3) in the ME among GnRH terminals, and (4) near a single GnRH neuron fiber in the POA (Fig. $1 B, C$ ). Release was observed when the electrode was near the intersection of soma and fibers, or between fibers (both $\mathrm{ME}$ and POA; Fig. $1 \mathrm{~B}, \mathrm{C}$ ), but not near single GnRH fibers even with $\mathrm{KCl}$ challenge (Fig. $1 B, C$ ). This provides functional evidence of $\mathrm{GnRH}$ release at $\mathrm{GnRH}-\mathrm{GnRH}$ junctions (Witkin and Silverman, 1985; Campbell et al., 2009).

\section{Differential detection of $\mathrm{GnRH}$ release in a model exhibiting diurnal changes in GnRH neuron activity}

The above correlation analyses revealed that FSCV accurately detects $\mathrm{GnRH}$ release in brain slices. We next tested its ability to measure biologically relevant changes using a model in which female mice exhibit estradiol-induced daily changes in $\mathrm{GnRH}$ neuron activity that are correlated with circulating LH levels (Christian et al., 2005). This reflects a switch from negative to positive estradiol feedback, and is a critical part of the female reproductive cycle (Döcke and Dörner, 1965; Moenter et al., 1991; Christian and Moenter, 2010). We hypothesized that similar daily changes in GnRH release occur. One-hour FSCV recordings of spontaneous $\mathrm{GnRH}$ release were made in the morning (low GnRH neuron activity) and afternoon (high activity) from both soma-fiber appositions in the POA (morning: $n=$ 8, afternoon: $n=5$ ) and ME (morning: $n=6$ A.M., afternoon: $n=5$ P.M.). No time-of-day differences were observed in the POA for concentration change, release duration, or frequency of release (Fig. 3). Interestingly, three of eight morning POA recordings had no spontaneous $\mathrm{GnRH}$ release, but exhibited $\mathrm{KCl}$ evoked release, indicating CFME was placed near a potential release site. The lack of spontaneous release is consistent with reduced activity of GnRH neurons at this time. ME GnRH release was longer in duration $\left(F_{(41)}=4.292, p<0.05\right)$ and exhibited greater concentration changes $\left(F_{(41)}=3.943, p<0.05\right)$ than in the POA regardless of time of the day. Further, release events in the ME were more frequent $\left(F_{(26)}=5.304, p<0.05\right)$ in the afternoon than in the morning. GnRH concentration changes were greater in the $\mathrm{ME}$ during both the morning and afteroon, suggesting more release sites than the POA.

\section{Discussion}

Here we demonstrate that FSCV allows real-time, specific monitoring of $\mathrm{GnRH}$ neurosecretion with good spatial resolution in brain sections. FSCV revealed several functional insights into the $\mathrm{GnRH}$ network. First, this is the first demonstration in native $\mathrm{GnRH}$ neurons that release occurs in regions other than the ME. Second, micromolar changes in $\mathrm{GnRH}$ concentration can occur at GnRH-GnRH appositions in the POA and in the ME, demon- 

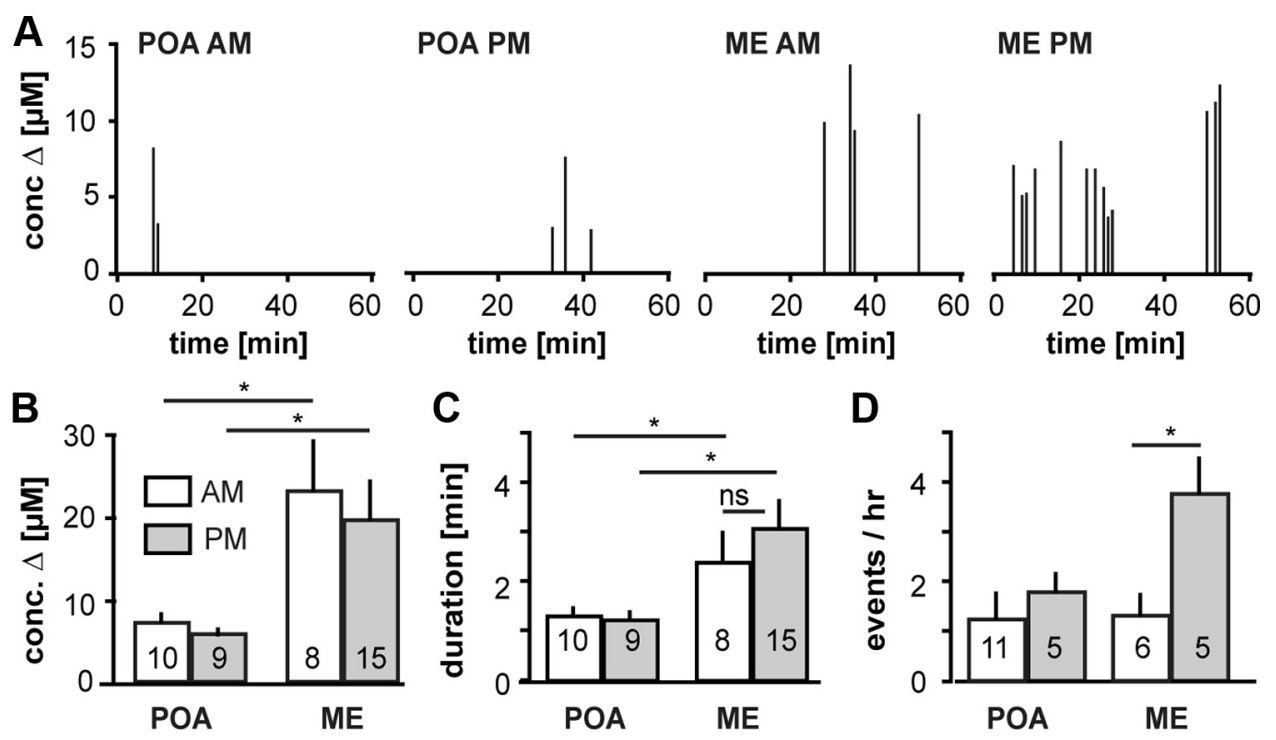

Figure 3. FSCV detects changes in GnRH release between two different biological states. $A$, Representative examples of the pattern of spontaneous GnRH release detected at CFMEs near GnRH soma/fiber appositions in the POA and fibers in the ME in ovariectomized mice treated with estradiol to induce diurnal changes in GnRH neuron activity (Christian et al., 2005). Data were collected in 1 min bins and each bar shows the maximum concentration in each bin. Multiple spikes in adjacent bin represent one long event. $\boldsymbol{B}-\boldsymbol{D}$, Mean \pm SEM concentration change (B), event duration ( $(\boldsymbol{C}$, and number of secretory events/h(D). Numbers in bars are number of cells (D) or number of events examined (B, C. AM, Morning; PM, afternoon; conc., concentration. ${ }^{*} p<0.05$.

strating that GnRH levels that are potentially autoexcitatory are achievable (Xu et al., 2004). Third, estradiol feedback differentially regulates $\mathrm{GnRH}$ release in the POA and ME. Together, these data suggest that multiple functions of $\mathrm{GnRH}$ and potential sitespecific regulation of release help sculpt overall output of this neurosecretory network.

In murine brain slices, $\mathrm{GnRH}$ release was detected in the POA only where two GnRH neurons appeared to interact, indicating that GnRH-GnRH junctions may mark release sites. Although the role of $\mathrm{GnRH}$ in the neuroendocrine control of the anterior pituitary is well established, it also acts as a neuromodulator within the brain. This was postulated from in vivo studies (DePaolo et al., 1987) and such actions have been demonstrated in brain slices (Xu et al., 2004, 2008; Chen and Moenter, 2009; Han et al., 2010). The detection of GnRH release at GnRH$\mathrm{GnRH}$ appositions in the POA provides intriguing evidence that $\mathrm{GnRH}$ neurons may use GnRH for modulation of their own function. Recent work in cultured embryonic GnRH neurons indicated GnRH was released from the soma and proximal processes (Fuenzalida et al., 2011). The present data support and extend these data by demonstrating that there is at least some degree of anatomical specification of release sites to GnRH$\mathrm{GnRH}$ appositions; further, the previous finding of perisomatic release was not attributable to an artifact subsequent to culturing.

FSCV does not allow for detection of absolute concentrations because of the required baseline subtraction; instead, changes in concentration attributable to secretion are monitored. This putative limitation may be an asset in the GnRH neuronal system given the episodic nature of $\mathrm{GnRH}$ release. Although absolute concentrations are not determined, the change in concentration measured by FSCV can be used to estimate local concentrations achieved upon release. GnRH release was measured in the micromolar concentration range both at $\mathrm{GnRH}-\mathrm{GnRH}$ appositions in the POA and within the ME. This high concentration may seem initially surprising given levels measured in pituitary portal blood (Sherwood et al., 1980; Moenter et al., 1992); however, those levels are quantified after diffusion and dilution in the blood. Further, estimates of synaptic cleft concentrations of transmitters are quite high; for example, GABA is in the millimolar range (Mozrzymas et al., 2003). The measurement of micromolar $\mathrm{GnRH}$ is of interest with regard to understanding dose-dependent changes in $\mathrm{GnRH}$ neuronal activity in response to $\mathrm{GnRH}$ (Xu et al., 2004). Nanomolar exogenous GnRH inhibited GnRH neuron activity, whereas micromolar GnRH increased activity (Xu et al., 2004). This may be attributable to different affinities of the GnRH receptor when coupled to different G-proteins (Millar et al., 2008). One hypothesis is that random fusion of $\mathrm{GnRH}$ vesicles produces low concentrations that inhibit the network, whereas action potentialdriven release of $\mathrm{GnRH}$ generates high concentrations that excite the system, perhaps contributing to coordination of pulsatile release or long-term release during the preovulatory GnRH surge (Moenter et al., 1991).

The present work validates FSCV for real-time detection of $\mathrm{GnRH}$ in brain slices. The technique is sensitive enough to detect release in the POA between two GnRH neurons, as well as the integrated output of the GnRH population in the ME. Future studies will determine how electrical activity correlates with release from terminals versus dendrites, and examine the function of $\mathrm{GnRH}$ release in different brain regions.

\section{References}

Abe H, Terasawa E (2005) Firing pattern and rapid modulation of activity by estrogen in primate luteinizing hormone releasing hormone-1 neurons. Endocrinology 146:4312-4320. CrossRef Medline

Belchetz PE, Plant TM, Nakai Y, Keogh EJ, Knobil E (1978) Hypophysial responses to continuous and intermittent delivery of hypopthalamic gonadotropin-releasing hormone. Science 202:631-633. CrossRef Medline

Cahill PS, Walker QD, Finnegan JM, Mickelson GE, Travis ER, Wightman RM (1996) Microelectrodes for the measurement of catecholamines in biological systems. Anal Chem 68:3180-3186. CrossRef Medline

Campbell RE, Gaidamaka G, Han SK, Herbison AE (2009) Dendrodendritic bundling and shared synapses between gonadotropin-releasing hormone neurons. Proc Natl Acad Sci U S A 106:10835-10840. CrossRef Medline

Chen P, Moenter SM (2009) GABAergic transmission to gonadotropinreleasing hormone $(\mathrm{GnRH})$ neurons is regulated by $\mathrm{GnRH}$ in a 
concentration-dependent manner engaging multiple signaling pathways. J Neurosci 29:9809-9818. CrossRef Medline

Chothia C (1976) The nature of the accessible and buried surfaces in proteins. J Mol Biol 105:1-12. CrossRef Medline

Christian CA, Moenter SM (2010) The neurobiology of preovulatory and estradiol-induced gonadotropin-releasing hormone surges. Endocr Rev 31:544-577. CrossRef Medline

Christian CA, Mobley JL, Moenter SM (2005) Diurnal and estradioldependent changes in gonadotropin-releasing hormone neuron firing activity. Proc Natl Acad Sci U S A 102:15682-15687. CrossRef Medline

Chu Z, Moenter SM (2005) Endogenous activation of metabotropic glutamate receptors modulates GABAergic transmission to gonadotropinreleasing hormone neurons and alters their firing rate: A possible local feedback circuit. J Neurosci 25:5740-5749. CrossRef Medline

DePaolo LV, King RA, Carrillo AJ (1987) In vivo and in vitro examination of an autoregulatory mechanism for luteinizing hormone-releasing hormone. Endocrinology 120:272-279. CrossRef Medline

Döcke F, Dörner G (1965) The mechanism of the induction of ovulation by oestrogens. J Endocrinol 33:491-499. CrossRef Medline

Fuenzalida LC, Keen KL, Terasawa E (2011) Colocalization of FM1-43, bassoon, and GnRH-1: GnRH-1 release from cell bodies and their neuroprocesses. Endocrinology 152:4310-4321. CrossRef Medline

Gill JC, Wadas B, Chen P, Portillo W, Reyna A, Jorgensen E, Mani S, Schwarting GA, Moenter SM, Tobet S, Kaiser UB (2008) The gonadotropinreleasing hormone $(\mathrm{GnRH})$ neuronal population is normal in size and distribution in GnRH-deficient and GnRH receptor-mutant hypogonadal mice. Endocrinology 149:4596-4604. CrossRef Medline

Han SK, Lee K, Bhattarai JP, Herbison AE (2010) Gonadotrophin-releasing hormone $(\mathrm{GnRH})$ exerts stimulatory effects on GnRH neurons in intact adult male and female mice. J Neuroendocrinol 22:188-195. CrossRef Medline

Ishizaki M, Oka Y (2001) Amperometric recording of gonadotropinreleasing hormone release activity in the pituitary of the dwarf gourami (teleosat) brain-pituitary slices. Neurosci Lett 299:121-124. CrossRef Medline

Kuehl-Kovarik MC, Pouliot WA, Halterman GL, Handa RJ, Dudek FE, Partin KM (2002) Episodic bursting activity and response to excitatory amino acids in acutely dissociated gonadotropin-releasing hormone neurons genetically targeted with green fluorescent protein. J Neurosci 22:2313-2322. Medline

Lee K, Duan W, Sneyd J, Herbison AE (2010) Two slow calcium-activated afterhyperpolarization currents control burst firing dynamics in gonadotropin-releasing hormone neurons. J Neurosci 30:6214-6224. CrossRef Medline

Mason AJ, Hayflick JS, Zoeller RT, Young WS 3rd, Phillips HS, Nikolics K, Seeburg PH (1986) A deletion truncating the gonadotropin-releasing hormone gene is responsible for hypogonadism in the hpg mouse. Science 234:1366-1371. CrossRef Medline

McCartney CR, Eagleson CA, Marshall JC (2002) Regulation of gonadotropin secretion: implications for polycystic ovary syndrome. Semin Reprod Med 20:317-326. CrossRef Medline

Millar RP, Pawson AJ, Morgan K, Rissman EF, Lu ZL (2008) Diversity of actions of $\mathrm{GnRHs}$ mediated by ligand-induced selective signaling. Front Neuroendocrinol 29:17-35. CrossRef Medline

Miller S, Janin J, Lesk AM, Chothia C (1987) Interior and surface of monomeric proteins. J Mol Biol 196:641-656. CrossRef Medline

Moenter SM, Caraty A, Locatelli A, Karsch FJ (1991) Pattern of gonadotropinreleasing hormone $(\mathrm{GnRH})$ secretion leading up to ovulation in the ewe: existence of a preovulatory GnRH surge. Endocrinology 129:1175-1182. CrossRef Medline

Moenter SM, Brand RM, Midgley AR, Karsch FJ (1992) Dynamics of gonadotropin-releasing hormone release during a pulse. Endocrinology 130:503-510. CrossRef Medline

Mozrzymas JW, Zarmowska ED, Pytel M, Mercik K (2003) Modulation of GABAA receptors by hydrogen ions reveals synaptic GABA transient and a crucial role of the desensitization process. J Neurosci 23:7981-7992. Medline

Mundroff ML, Wightman RM (2002) Amperometry and cyclic voltammetry with carbon fiber microelectrodes at single cells. Curr Protoc Neurosci Chapter 6:Unit 6.14. CrossRef Medline

Nunemaker CS, DeFazio RA, Moenter SM (2002) Estradiol-sensitive afferents modulate long-term episodic firing patterns of GnRH neurons. Endocrinology 143:2284-2292. CrossRef Medline

Nunemaker CS, Straume M, DeFazio RA, Moenter SM (2003) Gonadotropinreleasing hormone neurons generate interacting rhythms in multiple time domains. Endocrinology 144:823-831. CrossRef Medline

Paras CD, Kennedy RT (1995) Electrochemical detection of exocytosis at single rat melanotrophs. Anal Chem 67:3633-3637. CrossRef Medline

Pielecka J, Moenter SM (2006) Effect of steroid milieu on gonadotropinreleasing hormone-1 neuron firing pattern and luteinizing hormone levels in male mice. Biol Reprod 74:931-937. CrossRef Medline

Pielecka J, QuaynorSD, MoenterSM (2006) Androgensincrease gonadotropinreleasing hormone neuron firing activity in females and interfere with progesterone negative feedback. Endocrinology 147:1474-1479. CrossRef Medline

Sherwood NM, Chiappa SA, Sarkar DK, Fink G (1980) Gonadotropinreleasing hormone $(\mathrm{GnRH})$ in pituitary stalk blood from proestrous rats: effects of anesthetics and relationship between stored and released GnRH and luteinizing hormone. Endocrinology 107:1410-1417. CrossRef Medline

Strand AM, Venton BJ (2008) Flame etching enhances the sensitivity of carbon-fiber microelectrodes. Anal Chem 80:3708-3715. CrossRef Medline

Suter KJ, Song WJ, Sampson TL, Wuarin JP, Saunders JT, Dudek FE, Moenter SM (2000) Genetic targeting of green fluorescent protein to gonadotropinreleasing hormone neurons: characterization of whole-cell electrophysiological properties and morphology. Endocrinology 141:412-419. CrossRef Medline

Venton BJ, Troyer KP, Wightman RM (2002) Response times of carbon fiber microelectrodes to dynamic changes in catecholamine concentration. Anal Chem 74:539-546. CrossRef Medline

Wildt L, Häusler A, Marshall G, Hutchison JS, Plant TM, Belchetz PE, Knobil E (1981) Frequency and amplitude of gonadotropin-releasing hormone stimulation and gonadotropin secretion in the rhesus monkey. Endocrinology 109:376-385. CrossRef Medline

Witkin JW, Silverman AJ (1985) Synaptology of luteinizing hormonereleasing hormone neurons in rat preoptic area. Peptides 6:263-271. CrossRef Medline

Xu C, Xu XZ, Nunemaker CS, Moenter SM (2004) Dose-dependent switch in response of gonadotropin-releasing hormone $(\mathrm{GnRH})$ neurons to GnRH mediated through the type I GnRH receptor. Endocrinology 145: 728-735. CrossRef Medline

Xu C, Roepke TA, Zhang C, Rønnekleiv OK, Kelly MJ (2008) Gonadotropin-releasing hormone $(\mathrm{GnRH})$ activates the m-current in GnRH neurons: an autoregulatory negative feedback mechanism? Endocrinology 149:2459-2466. CrossRef Medline 